\title{
The Values of Motivation in Teaching and Learning Activities in St. Augustine's Major Seminary, Jos - Plateau State
}

\author{
Linus Pius Thliza ${ }^{a}$, Philip Daze Longdas ${ }^{b}$, Plangnan Danjuma Kumbat ${ }^{\mathrm{c}}$ \\ athlizamaria@yahoo.com, bphilipmark2005@gmail.com \\ aFormator, Theology Department, St. Augustine's Major Seminary, Jos \\ bAssistant Librarian, St. Augustine's Major Seminary, Jos \\ 'Department of General Studies Education, Federal College of Education, Pankshin
}

\begin{abstract}
The purpose of this article was to explore the importance of motivation in teaching and learning activities at St. Augustine's Major Seminary in Jos. With a total population of 329 participants, a descriptive survey design was adopted. The methods employed were stratified random sampling approaches. To gather data, a structured questionnaire with a five-point Likert scale was employed, and the results were presented as simple percentages using the Statistical Package for Social Sciences (SPSS) version 26. The results indicated that motivation is very crucial in the achievement of teaching and learning objectives, that formators are motivated by a positive atmosphere, that they get training and retraining, and that lecturers/formators are underpaid and in terrible working conditions. In conclusion, lecturers are not motivated to the highest possible level, and their low remuneration has a negative impact on their morale in the classroom. Despite the fact that reinforcement is used as a motivational technique in St. Augustine's Major Seminary, as demonstrated by the research, intrinsic motivation is more effective when students are exposed to values associated with the things they learn, as well as when they develop an interest for whatever it is that they are doing in their learning activities. Recommendations include that the salary of lecturers/formators be increased, as well as the quality of services provided, among other things.
\end{abstract}

Keywords: Values, motivation, teaching, learning activities

\section{Introduction}

Motivation is a major factor in human success, accomplishment, and determination. In order to have a good professional life, you need to be motivated. The most critical tool educators use to raise student achievement is motivation (Vero \& Puka, 2017). This is due to the fact that it encourages an individual's desire to learn, as well as a desire to work hard. Motivation must be a part of the educational system's culture and standard in order to accomplish great education. Educators, non-educators, and students all need to be inspired to work hard. Motivated employees put forth more effort and work longer hours to help the company achieve its objectives.

Teachers who are not motivated do not put forth the kind of work that those who are are not driven do (Jonathan, 2017). In order to improve the quality of instruction and student learning, it is critical that teachers be motivated. For the sake of implementing educational reforms and achieving the goals and objectives of the educational system, teachers who are driven tend to inspire and urge pupils to study in their classroom.

Many instructors nowadays lack motivation, which has a detrimental impact on both the quality of instruction and the quality of student learning. According to the findings of this study, this may be seen at St. Augustine's Major Seminary, Jos. Continuing to ignore this issue will have a negative impact on the way students and teachers are educated. That's why a study of motivation in teaching and learning is needed to address this issue.

Learning can only take place if pupils have the desire to put in the time, energy, and effort necessary to complete a specific activity, as well as to think about and feel about the work. There is a direct correlation between how much effort students put into their learning tasks and their capacity to persevere in the face of adversity. An alarming trend is emerging among the students at St. Augustine's Major Seminary in Jos: their academic 
performance is steadily deteriorating and they are becoming less enthusiastic about their studies. According to the findings of the aforementioned study, teachers' enthusiasm may spread to students and to the rest of the teaching and learning process as a whole. Thus, the importance of motivation cannot be overstated in the teaching and learning process.

St. Augustine's Major Seminary, Jos, needs to examine its current teaching and learning environment in order to enhance it for maximum performance. Looking at the motivational values of teaching and learning at this school might help. By conducting quantitative educational research and implementing its results, this study would be completed.

\section{Statement of the Problem}

For some time, it has been an issue of concern to the school administration, as well as bishops and congregational leaders responsible for the education and formation of seminary students. It is common for these children to be held responsible for their poor grades, which often results in their being expelled from school. How are these pupils supported to develop, despite their potential for being poor students? Many students have a preconception that language classes like Latin, Greek, and Hebrew are difficult, leading to a sense of helplessness and hopelessness. How well-versed are the instructors in teaching these languages, and are they using methods that will inspire their students? Teachers must be educated on teaching methods in general, as well as language teaching methods in particular. Some courses that students fail are taught by professors who are less often in class or who are irregular in language-related lectures, setting of questions, and grading. This has been seen in practice.

Is it possible that these instructors are really hindering students' ability to learn because they either don't teach enough or don't teach well enough, or because they aren't properly trained? Lecturers at the seminary often complain about low pay and terrible working conditions, which leads to poor performance. Many seminary instructors, if given the choice, would rather be elsewhere because they lack motivation and love for their vocation.

" Is it possible that their performance might be harmed as a result of these circumstances and attitudes? Distractions like social media, the internet, and sports are cited as major reasons why students are failing to pay attention in class. What if they could utilize the energy, they have from the reasons of their distraction to motivate them to study via various motivating approaches? Because of this, St Augustine's Major Seminary, Jos., has a pressing need to investigate the motivational values of teaching and learning in Jos.

\section{Objectives Of the Study}

This study aims to achieve the following objectives:

1. To find out what the values of motivation in teaching and learning are.

2. To find out why some students are not performing well academically in St Augustine's Major Seminary, Jos.

3. To find out to what extent has motivation affected the outcome of teaching and learning in St. Augustine's Major Seminary.

4. To suggest ways that learners and teachers in St Augustine's Major Seminary, Jos can be motivated for better performance. 


\section{Research Methodology}

A descriptive survey design was adopted for this research. Descriptive survey design aims to accurately and systematically describe a population, situation, or phenomenon. It answers what, where, when and how questions but not why questions. A population is the total number of people or items a researcher is interested in studying. The population of this study comprises 28 lecturers and 301 students, making the total of 329 as the population from St. Augustine's Major Seminary, Jos, Plateau State.

The sample size of this study was 181, which was gotten as a result of using the Yaro Yemene formula. Sample technique is the method used in selecting items, people, or objects for studying (Singh \& Masuku, 2014). Stratified random sampling techniques were used for this research. This method was selected because it dealt with a heterogeneous population. The researchers administered the questionnaire by themselves to the respondents and gave them some time to answer the questions before coming back to collect them. The data was analyzed using Statistical Package for the Social Sciences (SPSS) software, 26th version. To analyze the data, the data was coded as; 1- strongly disagree, 2-disagree, 3- undecide, 4- agree and 5- strongly agree and a simple percentage analysis was used for this research and the hypothesis was tested using chi-square.

\section{Analysis, Presentation and Discussion of Results}

Table 1: Motivation is not very important in teaching and learning activities

\begin{tabular}{llcc}
\hline & & Frequency & Percent \\
\hline Valid & Undecided & 22 & 12.9 \\
& Agree & 136 & 79.5 \\
& Strongly Agree & 13 & 7.6 \\
\cline { 2 - 4 } & Total & 171 & 100.0 \\
\hline
\end{tabular}

Source: Fieldwork, 2021

This research question indicates that $136(79.5 \%)$ respondents agree that motivation is very important in teaching and learning, 22 (12.9\%) were undecided and 13 (7.6\%) strongly agree with the statement. Therefore, this research reveals that motivation is very important in teaching and learning.

Table 2: Lecturers in St. Augustine's Major Seminary are motivated (Lecturers only).

\begin{tabular}{llcc}
\hline & & Frequency & Percent \\
\hline Valid & Strongly disagree & 2 & 20 \\
& Disagree & 5 & 50 \\
& Undecided & 1 & 10 \\
& Agree & 1 & 10 \\
& Strongly Agree & 0 & 0 \\
& Missing System & 1 & 10 \\
\hline Total & & 10 & 100.0 \\
\hline
\end{tabular}

Source: Fieldwork, 2021 
The above table reveals that the answers on whether lecturers in St. Augustine's Major Seminary are motivated, 5 (50 \%) agree, 2 (20\%) strongly disagree, 1 person undecided, agree and did not indicate. Hence it reveals that lecturers in St. Augustine's Major Seminary, Jos are not motivated.

Table 3: The use of motivational techniques can increase the interest of students

\begin{tabular}{llcc}
\hline & & Frequency & Percent \\
\hline Valid & Strongly disagree & 1 & 0.6 \\
& Undecided & 2 & 1.2 \\
& Agree & 48 & 28.1 \\
& Strongly Agree & 119 & 69.6 \\
& Missing System & 1 & 0.6 \\
\hline Total & & 171 & 100.0 \\
\hline
\end{tabular}

Source: Fieldwork, 2021

From the above table, the research shows that $119(69.6 \%)$ strongly agree, $48(28.1 \%)$ agree, $2(1.2 \%)$ have not decided and 1(0.6\%) strongly agree and has not indicated respectively, that the use of motivational techniques can increase the interest of students. Therefore, this result reveals that the use of motivational techniques can increase the interest of students in their learning activities.

Table 4: Lack of proper motivation is not part of the reason for the failure of some students

\begin{tabular}{llcc}
\hline & & Frequency & Percent \\
\hline Valid & Strongly disagree & 6 & 3.5 \\
& Disagree & 23 & 13.5 \\
& Undecided & 17 & 9.9 \\
& Agree & 72 & 42.1 \\
& Strongly Agree & 52 & 30.4 \\
& Missing System & 1 & 0.6 \\
\hline Total & & $\mathbf{1 7 1}$ & $\mathbf{1 0 0 . 0}$ \\
\hline
\end{tabular}

Source: Fieldwork, 2021

From the answer to the question "lack of proper motivation is part of the reason for the failure of some students", the above table indicates that $72(42.1 \%)$ agree, $52(30.4 \%)$ strongly agree, $23(13.5 \%)$ disagree, 17 $(9.9 \%)$ are undecided, $6(3.5 \%)$ strongly disagree and $1(0.6 \%)$ has not responded. Hence, this research shows that lack of proper motivation is part of the reason for the failure of some students.

Table 5: To a great extent, motivated lecturers can motivate students for better performance

\begin{tabular}{llcc}
\hline & & Frequency & Percent \\
\hline Valid & Disagree & 2 & 1.2 \\
& Undecided & 4 & 2.3 \\
& Agree & 61 & 35.7 \\
& Strongly Agree & 104 & 60.8 \\
\cline { 2 - 4 } & Total & $\mathbf{1 7 1}$ & $\mathbf{1 0 0 . 0}$ \\
\hline
\end{tabular}


Source: Fieldwork, 2021

From the above table, 104 (60.8\%) strongly disagree, 61 (35.7\%) agree, 4 (2.3\%) are undecided, $2(1.2 \%)$ disagree that to a great extent, motivated lecturers can motivate students for better performance. This research reveals that to a great extent, motivated lecturers can motivate students for better performance

Table 6: There is good remuneration of lecturers in St. Augustine's Major Seminary (for lecturers only)

\begin{tabular}{llcc}
\hline & & Frequency & Percent \\
\hline Valid & Strongly disagree & 2 & 20 \\
& Disagree & 4 & 40 \\
& Undecided & 2 & 20 \\
& Agree & 2 & 20 \\
& Strongly Agree & 0 & 0 \\
\hline Total & & $\mathbf{1 0}$ & $\mathbf{1 0 0 . 0}$ \\
\hline
\end{tabular}

Source: Fieldwork, 2021

The above table shows that 4 (40\%) disagree, 2 (20\%) strongly disagree, agree and are undecided respectively that there is good remuneration of lecturers in St. Augustine's Major Seminary. Therefore, the research concludes that there is no good remuneration for lecturers in St. Augustine's Major Seminary.

Table 7: The improvement of the condition of service is an important motivational technique

\begin{tabular}{llcc}
\hline & & Frequency & Percent \\
\hline Valid & Strongly disagree & 1 & 0.6 \\
& Disagree & 4 & 2.3 \\
& Undecided & 19 & 11.1 \\
& Agree & 82 & 48.0 \\
& Strongly Agree & 64 & 37.4 \\
& Missing System & 1 & 0.6 \\
\hline Total & & 171 & 100.0 \\
\hline
\end{tabular}

Source: Fieldwork, 2021

From the above table, 82 (48\%) agree, 64 (37.4\%) strongly agree, 19 (11.1\%) are undecided, $4(2.3 \%)$ disagree and $1(0.6 \%)$ strongly disagree and not responded respectively that the improvement of the condition of service is an important motivational technique. This result shows that the improvement of the condition of service is an important motivational technique. 
Table 8: There is ample use of reinforcement (reward and punishment) to improve the performance of students in St. Augustine's Major Seminary, Jos

\begin{tabular}{llcc}
\hline & & Frequency & Percent \\
\hline Valid & Strongly disagree & 9 & 5.3 \\
& Disagree & 28 & 16.4 \\
& Undecided & 29 & 17.0 \\
& Agree & 77 & 45.0 \\
& Strongly Agree & 27 & 15.8 \\
& Missing System & 1 & 0.6 \\
\hline Total & & $\mathbf{1 7 1}$ & $\mathbf{1 0 0 . 0}$ \\
\hline
\end{tabular}

Source: Fieldwork, 2021

To the question of whether there is ample use of reinforcement (reward and punishment) to improve the performance of students in St. Augustine's Major Seminary, Jos, 77 (45\%) agree, 29 (17\%) undecided, 28 (16.4\%) disagree, $27(15.8 \%)$ strongly agree, $9(5.3 \%)$ strongly disagree and $1(0.6 \%)$ not responded. Therefore, there is ample use of reinforcement (reward and punishment) to improve the performance of students in St. Augustine's Major Seminary, Jos.

Table 9: The use of intrinsic motivation is more effective in the learning activity of students

\begin{tabular}{llcc}
\hline & & Frequency & Percent \\
\hline Valid & Strongly disagree & 4 & 2.3 \\
& Disagree & 5 & 2.9 \\
& Undecided & 28 & 16.4 \\
& Agree & 93 & 54.4 \\
& Strongly Agree & 39 & 22.8 \\
& Missing System & 2 & 1.2 \\
\hline Total & & 171 & 100.0
\end{tabular}

Source: Fieldwork, 2021

The above table shows that $93(54.4 \%)$ agree, 39 (22.8\%) strongly agree, $28(16.4 \%)$ undecided, $5(2.9 \%)$ disagree, $4(2.3 \%)$ strongly disagree and 2 (1.2\%) not responded to the question. Hence, the analysis above supports the fact that the use of intrinsic motivation is more effective in the learning activity of students.

Table 10: There is teacher training and retraining in St. Augustine's Major Seminary, Jos

\begin{tabular}{llcc}
\hline & & Frequency & Percent \\
\hline Valid & Strongly disagree & 6 & 3.5 \\
& Disagree & 29 & 17.0 \\
& Undecided & 59 & 34.5 \\
& Agree & 54 & 31.6 \\
& Strongly Agree & 23 & 13.5 \\
\cline { 2 - 4 } & Total & 171 & 100.0 \\
\hline
\end{tabular}

Source: Fieldwork, 2021 
From the above table, 59 (34.5\%) undecided, 54 (31.6\%) agree, 29 (17\%) disagree, 23 (13.5\%) strongly agree and $6(3.5 \%)$ strongly disagree. Therefore, this research shows that there is teacher training and retraining in St. Augustine's Major Seminary, Jos.

Table 11: Lecturers are motivated by very conducive atmosphere in St. Augustine's Major Seminary, Jos

\begin{tabular}{llcc}
\hline & & Frequency & Percent \\
\hline Valid & Strongly disagree & 11 & 6.4 \\
& Disagree & 22 & 12.9 \\
& Undecided & 28 & 16.4 \\
& Agree & 62 & 36.3 \\
& Strongly Agree & 46 & 26.9 \\
& Missing System & 2 & 1.2 \\
\hline Total & & 171 & 100.0 \\
\hline
\end{tabular}

Source: Fieldwork, 2021

From the analysis of the above table, 62 (36.3\%) agree, 46 (26.9\%) strongly agree, $28(16.4 \%)$ undecided, $22(12.9 \%)$ disagree, $11(6.4 \%)$ strongly disagree and $2(1.2 \%)$ not responded. Hence, this shows that lecturers are motivated by the very conducive atmosphere in St. Augustine's Major Seminary, Jos.

Table 12: There is a cordial relationship between management and lecturers in St. Augustine's Major Seminary, Jos

\begin{tabular}{llcc}
\hline & & Frequency & Percent \\
\hline Valid & Strongly disagree & 1 & 0.6 \\
& Disagree & 8 & 4.7 \\
& Undecided & 34 & 19.9 \\
& Agree & 81 & 47.4 \\
& Strongly Agree & 47 & 27.5 \\
\cline { 2 - 4 } & Total & 171 & 100.0 \\
\hline
\end{tabular}

Source: Fieldwork, 2021

The analysis of the above table reveals that 81 (47.4\%) agree, 47 (27.5\%) strongly disagree, 34 (19.9\%) undecided, $8(4.7 \%)$ disagree and $1(0.6 \%)$ strongly disagree. This result shows that there is a cordial relationship between management and lecturers in St. Augustine's Major Seminary, Jos. 
Table 13: There is good relationship between lecturers and students in St. Augustine's Major Seminary, JoS

\begin{tabular}{llcc}
\hline & & Frequency & Percent \\
\hline Valid & Strongly disagree & 13 & 7.6 \\
Disagree & 14 & 8.2 \\
& Undecided & 22 & 12.9 \\
& Agree & 90 & 52.6 \\
& Strongly Agree & 32 & 18.7 \\
\cline { 2 - 3 } & Total & 171 & 100.0
\end{tabular}

Source: Fieldwork, 2021

The result of the above table shows that 90 (52.6\%) agree, 32 (18.7\%) strongly agree, $22(12.9 \%)$ undecided, $14(8.2 \%)$ disagree and $13(7.6 \%)$ strongly disagree. The analysis reveals that there is a good relationship between lecturers and students in St. Augustine's Major Seminary, Jos.

\section{Major Findings}

The findings of this study show that motivation is very important in teaching and learning. When teachers have a lot of motivation, they will be better at motivating other people, which will make their students want to do better. A good environment, training, and a good relationship with the seminary's management all help to motivate lecturers. However, this research shows that the level of motivation is low because of the way lecturers are paid and how they work. Even though the students of St. Augustine's major Seminary have good relationships with their lecturers and there is a lot of reinforcement, research shows that not having enough motivation is a big reason why students don't do well. Students who are motivated by their own desire to learn are more likely to improve their performance.

\section{Conclusion}

A look at this study shows that motivating students and teachers can be a huge help. Research shows that lecturers at St. Augustine's Major Seminary are not motivated to the best of their abilities, which is shown by low pay and the way they work. St. Augustine's Major Seminary needs to meet these motivators in order to be a good place to learn and teach. Motivated lecturers can be more effective at motivating students to do better work. People who study at St. Augustine's major seminary use reward as a motivator, but research shows that intrinsic motivation is more effective when students learn about values that are linked to what they learn and also become interested in what they do during their study time.

\section{Recommendations}

After the successful accomplishment of this study, necessary recommendations are very important for the implementation of results for the improvement of teaching and learning activities in St. Augustine's Major Seminary Jos. Below are some of the recommendations:

1. To improve the performance of lecturers and students of St. Augustine's Major Seminary, Jos, workshops and seminars are to be organized to create awareness about the values of motivation in teaching and 
learning activities. This will help both lecturers and students know what motivation is and how and when the different techniques of motivation could be employed for better performance in the institution.

2. The researchers recommends that the remuneration of the lecturers in St. Augustine's Major Seminary, Jos, be increased to motivate them for better performance. Also, the condition of service of the lecturers is reviewed to improve the welfare of lecturers so that their needs could be reasonably met. This must go beyond basic needs as stated in the hierarchy of needs theory of Abraham Maslow to avail lecturers the possibility of achieving their aspirations in life.

3. To improve the performance of students in St. Augustine's Major Seminary, Jos, the use of intrinsic motivation should be emphasized. This is aimed at helping students understand the value of choices they make and grow to love what they do and help them do things, not for external reward, but because it is worth doing. Students should be influenced to understand that engagement in academic activities helps in the use of their natural endowments like the intellect and other human faculties for proper human development.

4. Students should be helped to grow beyond the passing of exams and possessing of good results to impress their lecturers, bishops and parents, but work towards the acquisition of knowledge and on how to use this knowledge for their good and the good of others. Also, the fulfillment that comes from the acquisition of knowledge is a motivation in itself.

5. In the use of extrinsic motivation, students should be assisted to gaze on the society that awaits to share in their store of knowledge and how important academic excellence is for our world that is perishing for lack of knowledge. As adults, students should be helped by the seminary authority to go beyond reinforcement as a technique of motivation. This is because the use of reinforcement is more suitable for pupils in primary and secondary schools. 


\section{References}

Adebiyi, M. E., Al-Hassan, Y., Hansbourgh, C., Edginton, C., 2017. Values Attached to Educational Goals, Study Processes, and Educational Motivation. Journal of Education and Development, 1(1), pp. 48-57.

Ahmad, S. O. 2012, October 3. researchgate. Retrieved November 2021, from Research Gate: www.researchgate.net

Al-Aluf, W., Sudarsih, S., Musmedi, D. P., 2017. Assessing the impact of motivation, job satisfaction and work environment on the emlpoyee performance in health care services. International Journal of Scientific \& technolohy research, 6(10), pp. 337-341.

Alhassan, Z., 2020. Teacher Motivation as a Catalyst for Enhancing Quality Education in Nigeria. International Journal of Operational Research in Management, Social Sciences \& Education, 6(1), pp. 417-427.

Arendse, B., 2013. "Work motivation and satisfaction amongst employees in a financial services organisation in the Western Cape".

Carvalho, A. d., Raina, I. G., Soares, A. D., 2020. Motivation on job satisfaction and employee performance. Internation Research Journal of Management, IT \& Social Sciences, 7(5), pp. 13-23.

Chand, S., n.d. Motivation Theoris: Top 8 theoris of Motivation explained. Retrieved $1^{\text {st }}$ November 2021, from https://www.yourarticlelibrary.com/motivation/motivation-theories-top-8-theories-of-motivationexplained/35377

Dailey, A., 2009. Key Motivational factors and How Teachers can encourage Motivation in their Students. University of Birmingham.

Filgona, J., Sakiyo, J., Gwany, D., Okoronka, A., 2020. Motivation in Learning. Asian Journal of Education and Social Studies, 10(4), pp.16-37.

Hong, Y. C., Ganapathy, M., 2017. To investigate ESL Students' Instrumental and Integrative Motivation towars English Language Learning in a Chinese School in Penang: Case Study. English Language Teaching, 10(9), pp. 17-35.

Kuranchie-Mensah, E. B., Amponah-Tawiah, K., 2016. Employee Motivation and Work Performance: A Comparative Study of Mining Companies in Ghana. Journal of Industrial Engineering and Management, 9(2), pp. 255-309.

Latham, G. P., 2012. Work Motivation: History, Theory, Research and Practice (2nd Edition). Hage Publication.

Nyakundi, T. K., 2012. Factors affecting Teacher Motivation in Public Secondary Schools in Thika West District, Kiampu County.

Osakwe, R. N., 2014. Factors Affecting Motivation and Job Satisfaction of Academic Staff of Universities in South-South Geopolitical Zone of Nigeria. International Educational Journal, 7(7), pp. 43-51.

Ostinelli, G., 2016. The Role of Motivation and Understanding in the Change of Teaching Practices. Journal of Inquiry \& Action in Education, 7(2), pp. 111-128.

Polednova, I., Stranska, Z., Niedobova, H., 2014. Achievement motivation of secondary school students in relation to their social position in the class. Problems of Psychology in the 21st Century, 8(1), pp. 61-70.

Schuitema, J., Peetsma, T., Veen, I. V., 2016. Longitudinal relations between perceived autonomy and social support from teachers, and students' self-regulated learning and achievement. Learning and Individual Differences, 49, pp.32-45. 
Singh, A. S., Masuku, M. B., 2014. Sampling techniques and determination of sample size in applied statistics research: An overview. International Journal of Economics, Commerce and Management, 2(11), pp.122.

Steinhilber, B., 2018, April. 3 Types of motivation that can inspire you to do anything. Retrieved from nbcnews.com on $5^{\text {th }}$ November, 2021.

Taherdoost, H., 2016. Validity and Reliabity of the research instrument: How to test the validation of a questionnaire/survey in a research. International Journal of Academic Research in Management, 5(3), pp. 28-36.

Tastan, S. B., Davoudi, S. M., Masalimova, A. R., Bersanov, A. S., Kurbanov, R. A., Boiarchuk, A. V., Pavlushin, A. A., 2018. The impacts of teacher's efficacy and motivation on student's academic achievement in science education among secondary and high school students. EURASIA Journal of Mathematics, Science and Technology Education, 14(6), pp. 2353-2366.

Ting, S.-C., Wang, M. Y., Chou, M. J., 2014. A Study Of The Leisure Motivation and Satisfaction In The 2013 Taiwan Kaohsiung Chengcing Lake Balloon Festival. The International Journal of Organizational Innovation, 7(1), pp. 187-201.

Vero, E., Puka, E., 2017. Importance of Motivation in an Educational Environment. L'importanza della motivazione in un ambiente educativo. Formazione \& insegnamento XV, pp. 57-66.

Yusoff, M. S., 2019. ABC of content validation and content validity index calculation. Education in Medicine Journal, 11(2), pp. 49-54.

Zhang, Q. 2014. Assessing the effects of the instructor enthusiasm on classroom engagement, learning goal orientation, and academic self-efficacy. Communication Teacher, 28(1), pp. 44-56. 